\title{
LDH-C can be differentially expressed during fermentation of $\mathrm{CHO}$ cells
}

\author{
Berthold Szperalski ${ }^{*}$, Christine Jung ${ }^{1}$, Zhixin Shao ${ }^{1}$, Anne Kantardjieff ${ }^{2,3}$, Wei-Shou Hu² \\ From 22nd European Society for Animal Cell Technology (ESACT) Meeting on Cell Based Technologies \\ Vienna, Austria. 15-18 May 2011
}

\begin{abstract}
Expression of $\mathrm{CHO}$ mRNA was measured with special microarrays from the Consortium for Chinese Hamster Ovary $(\mathrm{CHO})$ Cell Genomics led by Prof. Wei-Shou Hu of the University of Minnesota and Prof. Miranda Yap of the

Bioprocess Technology Institute of A*STAR, Singapore

(http://hugroup.cems.umn.edu/CHO/cho_index.html). Cultivation experiments were performed in small scale $2 \mathrm{~L}$ stirred tank bioreactors. During fermentation a temperature shift of $-3^{\circ} \mathrm{C}$ was performed. This was accompanied by a reduction of the cell specific lactate production rate.

The analysis of transcriptome samples before and after the temperature shift with microarrays showed several changes in the expression of available gene markers. $\mathrm{LDH}-\mathrm{C}$ expression raised about 2 fold after temperature shift. LDH-A did not change. As LDH-C is known to be a specialized isoenzyme in sperm cells for consuming lactate in a lactate containing milieu, LDH-C could be proposed as a target for genetic engineering, facilitating lactate consumption in the late phase of high cell density cultures and prolonging longevity of $\mathrm{CHO}$ production cultures by reducing lactate and base accumulation.
\end{abstract}

\section{Methods}

CHO-cells producing a recombinant human antibody were cultivated in a proprietary proteinfree medium and inoculated in $4 \times 2 \mathrm{~L}$ stirred tank bioreactors. Bioreactors were controlling $\mathrm{pH}, \mathrm{pO} 2$ and temperature. A fixed feeding protocol was used to overcome the limitation of consumed medium components. Temperatures of 2 cultures were shifted at day 4 from $37^{\circ} \mathrm{C}$ to $34^{\circ} \mathrm{C}$. Daily samplings of the cultures were performed to monitor cell density and viability by using an automated Cedex $^{\text {TM }}$ cell counter and the trypan blue exclusion method. The supernatant of the culture was monitored for product concentration, glucose, glutamine, lactate, ammonium. Measurement of LDH (lactate dehydrogenase ) in cell culture supernatant was used as an indicator of cell lysis. Sedimented cells of cell culture samples were prepared and cRNA was processed according to Affymetrix $^{\text {TM }}$ standard procedures.[1] and hybridized with custom $\mathrm{CHO}$ Affymetrix ${ }^{\mathbf{T M}}$ arrays from the

\footnotetext{
* Correspondence: berthold.szperalski@roche.com

'Pharma Biotech, Roche Diagnostics GmbH, 82377 Penzberg, Germany

Full list of author information is available at the end of the article
}

Consortium for Chinese Hamster Ovary (CHO) Cell Genomics [2].

\section{Results}

The comparison of temperature shifted and control cultures showed significant differences in the growth curves of the experiment. Temperature shift induced an early shift to the plateau phase. It reduced the cell death. Cell specific productivity was slightly higher. Lactate consumption was higher and started earlier than in control cultures (data not shown). PCA (principal component analysis) was used to compare expression ratios at different temperatures. PC 1 showed that most expression changes are onset at day 6 and maintained throughout the rest of the culture. Transcriptome analyses showed several significant changes after the temperature shift (Table 1). One outstanding result is the upregulated RNA of LDH-C (Figure 1). LDH-A RNA expression showed no significant change after temperature shift.

\section{(Ciomed Central}

(c) 2011 Szperalski et al; licensee BioMed Central Ltd. This is an open access article distributed under the terms of the Creative Commons Attribution License (http://creativecommons.org/licenses/by/2.0), which permits unrestricted use, distribution, and reproduction in any medium, provided the original work is properly cited. 
Table 1

\begin{tabular}{cccc}
\hline Correlation to PC & Gene set & Number of genes in gene set & Nominal p-value \\
\hline Positive to PC 1 & Cell cycle & 26 & 0 \\
& DNA replication & 24 & 0 \\
& Cytoskeleton & 67 & 0.02 \\
& Microtubule organizing center & 24 & 0.04 \\
\hline Negative to PC 1 & Golgi apparatus & 50 & 0 \\
& Cell-cell signaling & 48 & 0 \\
\hline Positive to PC 2 & RNA processing & 43 & 0.01 \\
& Proteolysis & 46 & 0.05 \\
\hline Negative to PC 2 & DNA replication & 32 & 0.04 \\
\hline
\end{tabular}

\section{Discussion}

LDH-C is known to be present in sperm cells, testis cells and some tumors [3] but is not reported to be regulated in CHO-cell lines. In sperm cells LDH-C is known to have different kinetic properties compared to $\mathrm{A}$ and $\mathrm{B}$ isoforms of $\mathrm{LDH}$ preferring lactate as substrate
[4]. LDH-C is localized in cytoplasm and in specific "sperm type mitochondria" and seems to be integrated in a shuttle system for the transfer of reducing activity into the mitochondrial matrix [7][8]. An pseudogene association with mitochondrial cyclophilin D is reported in the gene bank of mouse genome [9]. The role of

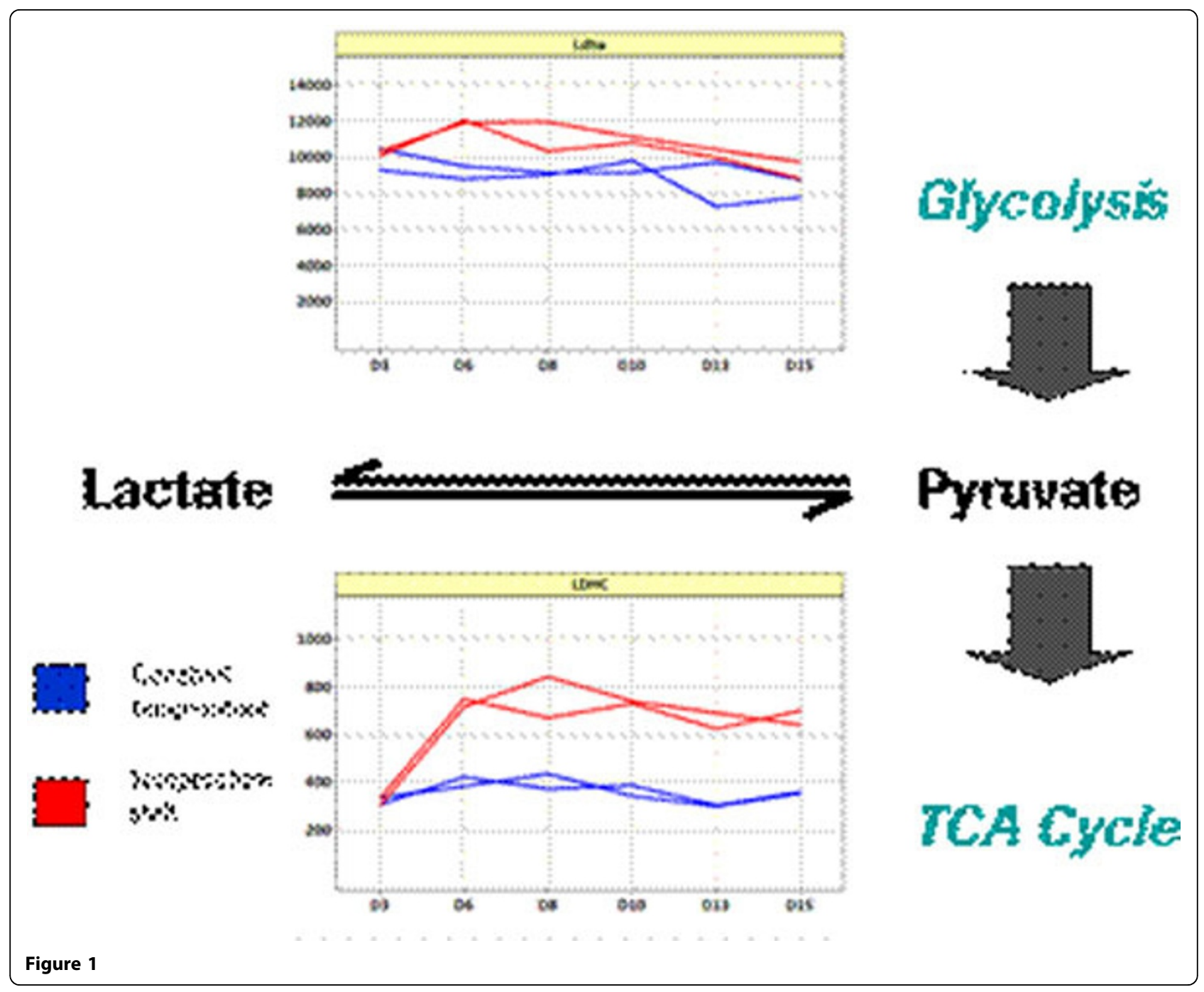


$\mathrm{LDH}-\mathrm{C}$ in CHO-Cells is still unclear. The influence of temperature shift under normal body temperature seems to induce a special situation for sperm cell migration. LDH-C helps sperm cells to survive in lactic acid containing micro milieus of the oviduct. It allows lactic acid to be an energy source. These functions could be mimicked in a high lactate containing, temperature shifted fermentation process with $\mathrm{CHO}$ cells. LDH-C can also be regulated by hormonal mechanisms. They are known to have slight regulatory influence on the transcriptional expression [5]. Selective inhibitors of LDH isoforms are described [6]. Specific inhibitors for LDH - $\mathrm{C}$ are proposed as antifertilizing drugs [6]. Inhibitors to $\mathrm{LDH}-\mathrm{A}$ and $-\mathrm{B}$ could help to favor $\mathrm{LDH}-\mathrm{C}$ and so reduce lactate production. $\mathrm{LDH}-\mathrm{C}$ is an interesting target for engineering manufacturing processes with cell lines like $\mathrm{CHO}$ cells for shifting these cells to aerobic lactate metabolism and improving growth performance.

\section{Author details}

${ }^{1}$ Pharma Biotech, Roche Diagnostics GmbH, 82377 Penzberg, Germany. ${ }^{2}$ University of Minnesota, Minneapolis, MN 55455, USA. ${ }^{3}$ Alexion

Pharmaceuticals, Cheshire, CT 06410, USA.

Published: 22 November 2011

\section{References}

1. Kantardjieff A, Jacob NM, Yee JC, Epstein E, Kok YJ, Philp R, Betenbaugh M, Hu WS: Transcriptome and proteome analysis of Chinese hamster ovary cells under low temperature and butyrate treatment. J Biotechnol 2010, 145:143-159.

2. Consortium for Chinese Hamster Ovary (CHO) Cell Genomics. 2007 [http://hugroup.cems.umn.edu/CHO/cho_index.html].

3. Koslowski M, Tureci O, Bell C, Krause P, Lehr HA, Brunner J, Seitz G, Nestle FO, Huber C, Sahin U: Multiple splice variants of lactate dehydrogenase $C$ selectively expressed in human cancer. Cancer Res 2002, 62:6750-6755.

4. Blanco A, Burgos C, Gerez de Burgos NM, Montamat EE: Properties of the testicular lactate dehydrogenase isoenzyme. Biochem J 1976, 153:165-172.

5. Ohsako S, Kubota K, Kurosawa S, Takeda K, Qing W, Ishimura R, Tohyama C: Alterations of gene expression in adult male rat testis and pituitary shortly after subacute administration of the antiandrogen flutamide. J Reprod Dev 2003, 49:275-290.

6. Yu Y, Deck JA, Hunsaker LA, Deck LM, Royer RE, Goldberg E, Vander Jagt DL: Selective active site inhibitors of human lactate dehydrogenases A4, B4, and C4. Biochem Pharmacol 2001, 62:81-89.

7. Burgos C, Maldonado C, Gerez de Burgos NM, Aoki A, Blanco A: Intracellular localization of the testicular and sperm-specific lactate dehydrogenase isozyme C4 in mice. Biol Reprod 1995, 53:84-92.

8. Gladden LB: Lactate metabolism: a new paradigm for the third millennium. J Physiol 2004, 558:5-30.

9. Mouse DNA sequence from clone RP23-313/15 on chromosome 13 Contains a peptidylprolyl isomerase D (cyclophilin D) (Ppid) pseudogene and a sperm specific lactate dehydrogenase $3 C$ (Ldh3) pseudogene, complete sequence. GenBank: AL606965.20; 2011 [http://www.ncbi.nlm. nih.gov/nucleotide/AL606965.20].

doi:10.1186/1753-6561-5-S8-P107

Cite this article as: Szperalski et al:: $\mathrm{LDH}-\mathrm{C}$ can be differentially expressed during fermentation of $\mathrm{CHO}$ cells. BMC Proceedings 20115 (Suppl 8):P107.

\section{Submit your next manuscript to BioMed Central and take full advantage of:}

- Convenient online submission

- Thorough peer review

- No space constraints or color figure charges

- Immediate publication on acceptance

- Inclusion in PubMed, CAS, Scopus and Google Scholar

- Research which is freely available for redistribution

Submit your manuscript at www.biomedcentral.com/submit
C Biomed Central 